\title{
INDIGENOUS THOUGHT, IMPOSED THEORY \\ A NOTE WITH REFERENCE TO CONSUMER THEORY
}

\author{
SHANKARAN NAMBIAR
}

\section{Perceptions of Economic Theory}

The world-view encapsulated within neo-classical enconomic theory seldom comes under criticism for not espousing man as a being striving for transcendence. In other words, there are valid reasons why the worldview of economic theory must be compared with the world-view of traditional Indian thought. Sure enough economic theory is criticised, but this criticism is normally of two types. On one hand there are the critics who, belonging to the same community, attack the assumptions supported by their opponents with a view towards imposing further restrictions upon the assumptions or in order to relax the assumptions so as to achieve further generality. Critics of this sort, when they attack the main body of theory, do so to achieve greater technical clarity, taking care to include new features that, probably, would explain the 'real' world better and excluding features that provide a confused picture of the 'real' world. The common faith shared by this community of social scientists is a belief in their theoretical framework and the certainty that their apparatuses can actually picture the logical structure of the economic world, altering or refining their apparatuses as they go along. The other important and active group of critics are those who hold the opinion that neo-classical economic theory provides a distorted view of reality since the neo-classicists study the apparent, excluding from their purview the actual underlying play of forces. Thus, exchange relations are studied to the sole exclusion of what goes on and behind to determine the dynamics of production. This confusion of the virtual for the real, this obsession with commodities, this temporal abstraction, it is argued, is intentional. Theory, more precisely neo-classical economic theory in this case, the second group of critics say, is the intentional and conscious distortion of reality by the bourgeoisie to cloud the importance of labour and to weaken the claims of the proletariat.

For Marx, the proletariat is in an unpriviledged position under capitalism. The proletariat, receiving just the historical and cultural minimum to satisfy its requirements for biological sustenance and reproduction, ${ }^{1}$ offers its surplus labour to further the capital accumulation of the bourgeoisie. ${ }^{2}$ The activities of the proletariat are therefore restricted to the necessities of life, that realm of life which, properly speaking, belongs to the private sphere. ${ }^{3}$ 
Further, in the capitalist mode of production the production process is divided into parts, each part requiring individual attention. The worker consequently engages himself with one aspect of production ${ }^{4}$ that could easily be performed, quite mechanically, by workers involved with other aspects of production. One aspect of production requires as little specialisation as another aspect. The division of labour, a characteristic of capitalism, does away with specialisation and with the joy of creating a complete product. The joy of working is now simply reduced to labouring. ${ }^{5}$ Marx's schematisation is then justly enough devoted towards acquiring freedom for the proletariat from the bonds of necessity and from the humiliation of alienation. ${ }^{6}$ The proletariat does not 'transcend' his position. Instead, a dictatorship of the proletariat is established, and with the withering of the state it becomes possible to engage in the worldless pursuit of "hobbies" 7 (hunting, fishing, criticising) rather than in professions - labour power need not find its worth in the market-place. This liberation is a process of the world, the result of a transition from capitalism to a more advanced mode of production, quite a different preoccupation from the Hindu one of going beyond all worldly structures, one where the primacy of the Self exceeds all other concerns.

The classical economists, forefathers of the neo-classical stream, support a laissez-faire economy. They advocate the free and unrestricted interaction of demand and supply, arguing that such free and unhindered interaction will not result in anarchy, but in an economy where the 'invisible hand' 8 will ensure the right distribution of commodities. Government intervention is therefore ruled out of such a conceptualisation. The government, if it is to have any function, must act as a watch-dog, taking care to see that the free interplay of demand and supply forces which ensure equilibrium is not in any way disrupted. The economy in this scheme of thinking is thought to be governed by homeostatic principles: the economic 'organism' takes care of itself: excesses and deficits elicit controls that come in the form of disincentives or incentives, as the case may be. The man in classical economics can reliably depend on his 1) behavioural responses and, 2) his self-interest. On the basis of his self-interest one can expect this man to supply less when there is less demand, and to supply more when there is more demand. And all production in this economy will be motivated not by love for one's neighbour, but according to the dictates of one's selfinterest. ${ }^{2}$ In these fundamental respects neo-classical economics shares in the conceptualisations of the classicists; they differ only in so far as the neoclassicists incorporate marginal analysis, lay down optimality conditions, etc. Neo-classical economic theory validifies itself with a self-pronounced claim to universality, but as we shall see the characterisation of man in 
neo-classical economic theory fails to accomodate the world-view encompassed by Hindu thought.

\section{Consumer Theory ${ }^{10}$ And Traditional Concerns}

At first glance it might seem a curious, if not parochial interest to examine to what extent the world-view inherent within neo-classical economic theory and that accepted by traditional Indian thinking diverge. Such an interest is not entirely out of place. Men have their world-views and their life-goals. These have a historicity and cultural specificity of their own, and it also cannot be denied that these values largely determine the range of actions that may be committed. In a sense, world-views ensure a limit to actions. Since it is believed that the usefulness of a social science lies in its ability to predict and control the social world, economic theory, like any other social science, must derive its principles from foundations that are technically and culturally acceptable. Technically acceptable foundations ensure the elegance and generality of theoretical results; and culturally acceptable foundations ensure that the image of man created in theory corresponds with the image of man accepted by society. The second condition merely guarantees that the man in society of whom the social scientists speaks bears a relationship with the man in society as society sees. This insistence bears out of a desire to safeguard the interests of the human beings who are the subjects of discourse. Because social scientists decide what the wishes and objectives of a society must be before measuring certain indicators and creating certain theoretical relationships that are eventually used to alter the environment of the subjects, it is absolutely essential that the subjects of discourse be a relevant and meaningful transformation of the subjects in life. Besides, it is certainly not out of place to note how the world-view of economic theory and Hindu thought diverge when they are constantly forced to interact with each other.

Consumer theory best reflects the main strands of thought that form the basis for much of economic theory.. It is as a result of what is developed in consumer theory that economic theory finally builds itself into planning theory and economic policy, those monolithic structures that try to alter human conditions. Quite simply, consumer theory attempts at a modelling of man's behaviour in a world of goods. This is an interesting area to consider: one, because, as mentioned, without clarifying one's grounds here no further theorisation of the economic world is possible. Second, Hindu thinking has gone into this area, as it must unless it wishes to ignore the immediate reality of objects that have use and that can satisfy certain human wants - and Hindu thought has no intention of ignoring the phenomenal world. Rather, it wishes to clarify and deepen our perception of the phenomenal world we encounter everyday. 
The theory of consumer choice does ot take consumer preferences as they are observed. In order to theories about choice certain assumptions, known as "rationality" assumptions, are imposed on consumer preferences. All preferences are then judged by way of this pre-determined construct. Consumer theory, to put it another way, does not study choices as they are made in the market-place or in shops. Rather, some restrictions that are supposed to be universally applicable are first laid out in advance, and it is through these restrictions that particular situations are studied. Hence, actions are judged to be rational not if they seem rational to the persons involved within a particular context, but if the actions performed within some context conform to pre-determined criteria.

Not only does consumer theory refuse to accept what is observed on its own terms, consumer theory also denies all criteria of choice and preference that precede it. As far as consumer theory will see, that a certain commodity bundle $x$ is preferred to another commodity $x^{\prime}\left(x>x^{\prime}\right)$ is all that is required. The facticity of $x>x^{\prime}$ is taken as self-evident. Consumer theory chooses not to examine why such a choice is made. In its acultural, moral lenience it does not bother why a consumer makes such a choice or if he can explain such a choice. Consumer theory in not allowing its notion of individual preference to be derived from any previous analysis, consertedly disacknowledges all the injunctions, rules and traditional habits so closely adhered to by Indians. In India, explanations for a choice can be more important than choosing at all. For example, for many (millions) a smaller bowl of dhal will be prefered to a larger bowl that contains garlic, because of the nutritional beliefs they hold. If there are only two bowls of dhal and both contain garlic then nothing will be preferred to something. This shows how other codes of choice can throw consumer theory off its seat even if consumer theory blinds itself to their existence. Just to depend on whether consumers can rank preferences, not on why they rank as they do, and to go by simplistic rules like "more is preferred to less" can lead to difficulties, thereby necessitating an explanation at the margins of empirical work of what ought to have been incorporated at the heart of theory. Consumer theory when confronted with difficulties like the one pointed out in our example, resorts to the denigration ('backwardness', 'unscientific' beliefs; 'irrationality') of the incompatible phenomena. This is the inevitable cost of refusing to accept worlds that precede and interact with consumer theory.

The world of consumer theory again diverges greatly from the Hindu world with regard to the manner in which both these worlds look upon commodities or goods. The consumer theorist sees the consumption bundle as a source of "utility" or "satisfaction." It is this flow of satisfaction from commodities that makes them attractive. For the consumer theorist it is 
perfectly human to be attracted by the satisfaction that can be derived from commodities and to try to attain higher levels of satisfaction. The attraction of commodities is willingly, even eagerly, sought. But a similiar enthusiasm is not shared in the Hindu world. The Hindu is urged to be "victorious over the sense-instruments," 11 he is reminded of the "boundless happiness that lies beyond sense-instruments." ${ }^{12}$ The Hindu is therefore wary of the temptation of goods. The satisfaction that commodities can give is a triviality that must be passed over, otherwise one would be restricting oneself to the illusory world. Lao Tzu, though of a different tradition, reflects Hindu thought accurately when he says:

The five colors darken the eye;

The five sounds will deaden the ear;

The five flavors weary the taste;

Chasing the beasts of the field

Will drive a man mad. ${ }^{13}$

Lao Tzu is aware that commodities of quality, goods that are fine, are not easily obtained; but he is equally aware that difficult as it may be to possess them, the sensual pleasure they provide only serves to restrain a man. So:

The goods that are hard to procure

Are hobbles that slow walking feet. ${ }^{14}$

Consequently, we are warned that, ironically enough, the greater the satisfaction that can be derived from commodities the more constraining they turn out to be. The man in the world of Hindu thought, quite unlike the man imaged in consumer theory, does not direct himself towards reaching higher and higher levels of utility, he does not ask to be on the highest possible indifference curve.

The problem of consumer choice, in economic theory, may, however, be represented as that of attaining the highest possible utility function given one's income. The man of consumer theory is posited as a utility-maximiser. That is the best he can do within the ambit of consumer theory. It is conceivable within this tradition, and as a preparation for its objectives, that a consumer can choose "any finite non-negative amount of each commodity." On the other hand the Hindu knows only the Infinite to be bliss: "There is no bliss in anything finite," 15 because "Infinity only is bliss." 16 The finite, the relative, is a clue for what lies beyond it, one does not dwell upon it. Instead, "that by which we know form, taste, smell, sounds and loving touches, by that also we know what exists besides." ${ }^{17}$ To use one's sensory organs for a lesser purpose - say, to accumulate further satisfaction, utility - would lead to a "fall into the snare of widespread death," 18 the natural consequence of looking "for anything stable here among things unstable." 19 
Stated differently, the senses are called the horses, the objects of senses their roads and the destination is designated as that point which is the "highest place of Vishnu." ${ }^{20}$ The end of this journey is beyond the senses, beyond the objects, beyond even the mind, the intellect, the Great Self, even beyond purusha, and here "beyond purusha there is nothing - this is the goal, the highest road." ${ }^{21}$ The goal transcends all earthly concerns and can only be located in paradoxical terms as "the Infinite (that) indeed is below, above, behind, before, right, and left - it is indeed all this." 22

While the consumer theorist chooses to maximise his satisfaction, the Hindu desire is to go beyond the confinement of commodities. The Hindu wishes to realize "the majesty of the Self," ${ }^{23}$ so that "established in yoga" 24 he may perform action, because only then can he be freed from the binding effects of action. Those who die without naving discovered the Self (which is "to be described by No, no!" ${ }^{25}$ ) have "no freedom in all the worlds" 26 and pass "from death to death." ${ }^{27}$ The consumer theorist in turn is introvertive: he turns his attention away from the individual towards abstract concerns that have no value in human endeavours.

This introvertiveness finds clear expression in the convexity condition employed by consumer theorists. The assumption of strict convexity considers two consumption bundles, say, $x$ and $x$ ' within the consumption space. If $x$ is at least as good as $x^{\prime}$, then those points which are the convex combination of $x$ and $x$ ' lying on the interior of the straight line drawn between $x$ and $x^{\prime}$ are said to be strictly preferred to $x^{\prime}$. Geometrically, in twocommodity space, the requirement imposed by strict convexity would permit only indifference curves that are convex to the origin. The focus is on the point of origin - whether the indifference curves are convex to the origin or concave to the origin.

The characteristics' approach ${ }^{28}$ in consumer theory again exemplifies consumer theory's orientation towards the non-human. The 'characteristics' approach works on the hypothesis that consumers are not interested in goods per se, but in the characteristics goods possess. So, it is argued, when consumers purchase, say, apples, it is not some amorphous property of "appleness" which they wish to consume, but the vitamin and calorific content in apples, to limit ourselves to two properties. Thus consumers will consider various types of apples in terms of how many units they possess of one rupee's worth of vitamin-content and one rupee's worth of calorific content. Consumers will choose those apples (one type or a particular selection of different types) that have the most efficient combination of characteristics. Consumer theory, not satisfied with its treatment of commodities as one homogenous, consolidated whole spends its attention on delving into commodities, identifying and separating 'commodities' 
within commodities, 'commodities' (characteristics) which cannot be properly quantified and of which consumers themselves are only vaguely aware. While consumer theory continually buries itself under the burden of nonhuman considerations, attributing life to them as if in justification, Hindu thought hopes for nothing less than transcendence.

\section{Conclusion}

Social scientists must be cautious and suspicious of the inherent dangers involved in the enterprise of employing a social science whose values are completely unrelated to those espoused by the people upon whom it is imposed. If economic theory were a mere academic curiousity no one would be harmed. But economics is not content with modelling, measuring, and studying Indian society; it has the larger function of predicting, controlling and altering society. With a theoretical framework that does not accomodate the indigenous world-view, it can be expected of economics to arrive at incorrect picturisations of Indian society; economic science will try to explain what it is not properly equipped to explain. It will, from its world-view, find Indian society to be backward, sluggish, ${ }^{29}$ etc; and on the basis of these judgements it will suggest policy changes. Economics may then very well act as a self-fulfilling prophecy, dragging a whole society out of its own conceptualisations to conceptualisations that are foreign to its traditions, recreating a society in the image of another. This is the worst that can happen. Or, we will find a social science that, perpetually faced with phenomena not in accord with its theory, is continually trying to explain the 'non-economic' reasons for these divergences. Then we will have an unsuccessful social science that would insist on its subjects changing themselves to fit its theory. 
Jurnal Pengajian India

\section{NOTES}

1. Karl Marx, “Capital,” (London: Lawarence and Wishart, 1954), Vol. 1, p. 168.

2. Karl Marx, "Theories of Surplus Values," (London: Lawrence and Wishart, 1969), Vol. 2, pp. $405-6$.

3. For a thorough disuccsion on the private sphere, see Hannah Arendt, "The Human Condition," (Chicago: The University of Chicago Press, 1958), Ch. 2, pp. $22-78$.

4. Karl Marx (Note 1), p. 458.

5. On the distinction between "working" and "labouring," Arendt points out that, "the word "labour" understood as a noun, never designates the finished product, the result of labouring, but remains a verbal noun to be classed with the gerund, whereas the product itself is invariably derived from the word for work, even when current usage has followed the actual modern development so closely that the verb form of the word "work" has become rather obsolete," (Note 3), pp. $80-1$.

6. Karl Marx, "Selected Writings," ed. D. Mc Lellan, (Oxford: Oxford University Press, 1977), p. 89.

7. "Every activity unconnected with labour," argues Arendt, "becomes a "hobby." (Note 3), p. 128.

8. Adam Smith, "The Wealth of Nations," ed. by E. Cannan, (New York: Modern Library, Inc., 1937), p. 423.

9. Adam Smith (Note 8), p. 14.

10.The discussion on consumer theory is based on: H.A. Green, "Consumer Theory," (Harmondsworth, Middlesex: Penguin, 1971), J.R. Hicks, "Value and Capital," (Oxford: Clarendon Press, 1939), J.R. Hicks, "A Revision of Demand Theory," (Oxford: Clarendon Press, 1956), L. Phlips, "Applied Consumption Analysis," (Amsterdam: North Holland, 1974) and R.R. Russel and M. Wilkinson, "Microeconomics: A Synthesis of Modern and Neoclassical Theory," (New York: John Wiley and Sons, 1979).

11.Bhagavadgita, VI, 8 .

12. Bhagavadgita, VI, 21.

13. Tao Te Ching, 12.

14. Tao Te Ching, 12.

15. Chhandogya Upanishad, VII, xxiii.

16. Chhandogya Upanishad, VII, xxiii.

17. Katha Upanishad, II, iv, 3 .

18. Katha Upanishad, II, iv, 2.

19. Katha Upanishad, II, iv, 2.

20. Katha Upanishad, I, iii, 4; 9.

21. Katha Upanishad, I, iii, 11.

22. Chhandogya Upanishad, VII, xxv, 1.

23. Katha Upanishad, I, ii, 20.

24. Bhagavadgita, II, 48.

25. Brihadaranyaka Upanishad, IV, v, 15.

26. Chhandogya Upanishad, VII, 1, 6.

27. Katha Upanishad, II, iv, 10.

28. K. Lancaster, "A New Approach to Consumer Theory," Journal of Political Economy, 74, 1966, pp. $132-57$.

29. Consider this for instance: “ . . . . one of India's foremost economists, the late Prof. Raj Krishna, blamed the stagnancy (in growth rates) on the country's dominant religion and called it the "Hindu rate," "Far Eastern Economic Review, 17 October 1985, p. 83. 